\title{
Fostering Leadership Skills of Technology Professionals in Startups
}

\author{
Maria Lydia Fioravanti, ICMC-USP, mlfioravanti@usp.br, \\ https://orcid.org/0000-0002-3040-700X \\ Paulo H. S. de Morais, ICMC-USP, phsapiodemorais@gmail.com, \\ https://orcid.org/0000-0001-9060-4120 \\ Ellen Francine Barbosa, ICMC-USP, francine@icmc.usp.br, \\ https://orcid.org/0000-0003-3275-2293
}

\begin{abstract}
This paper presents an investigation on how the startup environment fosters the development and improvement of the leadership skills of technology professionals. From the beginning of the 90s, new products and new technologies began to appear at a much faster pace and, since then, significant changes have occurred in corporate, academic environments and in everyday interpersonal relationships. In this scenario, new types of business have also emerged, such as startups, considered an innovative enterprise, with the potential to grow and scale. Minds ahead of all this innovation were necessary and, therefore, a new type of leader emerged. A leader who not only guides the followers but encourages leadership by them. Particularly in the startup environment, leadership becomes even more fundamental. As these entrepreneurs must keep these organizations in constant and strong growth, the ability to manage and motivate people to follow the same path becomes an essential part of the process. In this context, we aimed to answer the following research question: "How do the startup environments foster the development and improvement of the leadership skills of technology professionals?". Aiming to answer the posed research question, we conducted a case study with four subjects. In this paper, we discuss each step of the case study and present the gathered results. As a result, we have identified three main categories of factors that promote the development and improvement of such professionals: open culture, leadership skills, and accelerated growth.
\end{abstract}

Keywords: Leadership, Technology Professionals, Startup Environment, Enterpreneurship

\section{Aprimorando as Habilidades de Liderança dos Profissionais de Tecnologia em Startups}

Resumo: Este artigo apresenta uma investigação sobre como o ambiente de startups promove o desenvolvimento e o aprimoramento das habilidades de liderança dos profissionais de tecnologia. A partir do início da década de 90, novos produtos e novas tecnologias começaram a surgir em um ritmo muito mais acelerado e, desde então, mudanças significativas ocorreram nos ambientes corporativos, acadêmicos e nas relações interpessoais do dia a dia. Nesse cenário, também surgiram novos tipos de negócios, como o startups, considerado um empreendimento inovador, com potencial de crescimento e escala. Mentes à frente de toda essa inovação eram necessárias e, portanto, um novo tipo de líder surgiu: um líder que não apenas orienta os seguidores, mas também incentiva a liderança por parte deles. Particularmente no ambiente de startups, a liderança se torna ainda mais fundamental. Esses empreendedores devem manter essas organizações em constante e forte crescimento, a capacidade de gerenciar e motivar as pessoas a seguirem o mesmo caminho torna-se parte essencial do processo. Nesse contexto, o presente trabalha visa responder à seguinte questão de pesquisa: "Como os ambientes de startups promovem o desenvolvimento e o 
aprimoramento das habilidades de liderança dos profissionais de tecnologia?". Com o objetivo de responder à questão de pesquisa colocada, foi realizado um estudo de caso com quatro sujeitos. Neste artigo, são discutidas as etapas do estudo de caso e apresentados os resultados obtidos. Como resultado, foram identificadas três categorias principais de fatores que promovem o desenvolvimento e o aprimoramento desses profissionais: cultura aberta, habilidades de liderança e crescimento acelerado.

Palavras-chave: Liderança, Profissionais de Tecnologia, Ambientes de Startups, Empreendedorismo

\section{Introduction}

In today's rapidly changing global economy, organizations are fraught with an increasingly complex, and volatile, unpredictable, chaotic, and ambiguous (VUCA) business environment (HORNEY; PASMORE; O'SHEA, 2010). From the beginning of the 90s, new products and new technologies began to appear at a much faster pace and, since then, significant changes have occurred in corporate, academic environments and in everyday interpersonal relationships (ISMAIL, 2014).

A concept that has become popular in the last decade is entrepreneurship. The art of transforming ideas into executable projects and making reality through the effort and dream of a disruptive mind has been addressed and seen more and more. For Hisrich and Brush (1985), entrepreneurship is the dedication of time and effort to create something that has value and that is innovative in some way, taking the necessary risks and receiving the financial and social consequences in return.

Entrepreneurship and innovation are correlated when the idea to be transmitted goes through the proposal to bring a concept that defines any of these words. Schumpeter (1928) defines that "the essence of entrepreneurship is in the perception and taking advantage of new opportunities in the scope of business".

Currently, entrepreneurship has been considered very important for world economic growth (THAI; TURKINA, 2014). Governments are increasingly aware of this transformation due to the benefits brought about and likely to encourage initiatives like this to take place, since social growth is also noticeable (BRUTON; AHLSTROM; LI, 2010).

Work environments with a high predominance of hierarchy and plastered processes have become obsolete in the face of more dynamic relationships in which everyone has access to information and it circulates almost instantly. In this scenario, new types of business have also emerged, such as startups, considered an innovative enterprise, with the potential to grow and scale. Minds ahead of all this innovation were necessary and, therefore, a new type of leader emerged. A leader who not only guides the followers but encourages leadership by them.

This innovation linked to entrepreneurship started the emergence of startups. According to Ries and Sałbut (2012), "a startup can be understood as a human institution designed to offer new products and services in scenarios of extreme uncertainty". In a related perspective, we can mention the fintechs, which are organizations with startup DNA, focused on bringing innovative solutions to the financial market environment. Lee and Shin (2018) characterize fintech as "a revolutionary disruptive innovation, capable of shaking traditional financial markets".

The willingness of some people to offer new solutions through technology in the market lies in the overlap between startup and entrepreneurship. According to Ries and 
Sałbut (2012), entrepreneurs in front of these companies must ensure that they remain at a strong pace of growth and remain healthy throughout this stage. These companies, therefore, can be characterized as modern companies, in which not only their main leader as well as their employees have the profile of an entrepreneur (RIES, 2017).

Covey (2017) considers that leadership is achieving, through clear communication, making people, by themselves, able to see its value and its potential. Still, leading means inspiring people to find their purpose and thus influencing behaviors so that they follow a single direction in favor of the organization or company (COVEY, 2017). Therefore, leadership can be highlighted as a very powerful and extremely necessary tool for the establishment of a strong culture. Daft (2021) states that "an organization's culture usually begins with a founder or a pioneering leader who articulates and implements particular ideas and values such as a vision, a philosophy or a business strategy".

Particularly in the startup/fintech environment, leadership becomes even more fundamental. As these entrepreneurs must keep these organizations in constant and strong growth, the ability to manage and motivate people to follow the same path becomes an essential part of the process. According to Lidow (2014), the leader of a startup must have the following skills: self-knowledge, knowledge of the business, knowing how to guide change, being motivated and building good relationships. Leaders need multiple skills to run a business (ZAECH; BALDEGGER, 2017) and, therefore, being prepared to use different approaches and adaptability for each context are necessary skills for a leader (ZAECH; BALDEGGER, 2017).

Thus, we can notice that more importance is given to the soft skills rather than to the technical skills of the professionals. In this sense, the importance of soft skills has been expounded repeatedly as a crucial factor to thrive in the workplace, as opposed to mere knowledge of content, since it is important to be able to adapt to new situations. We can observe, therefore, that the entrepreneurs who lead this movement have several skills in common, although there is a plurality. Among such skills, we can mention: dynamism, dedication, taste for risk, vision to see opportunities, leadership, and so forth.

In order to investigate the influence of the startup environment on leadership skills, we conducted a case study with four subjects. In this paper, we investigate how startup environments foster the development and improvement of the leadership skills of technology professional by means of a case study. In short, we can highlight that, as a result, we have identified three main categories of factors that promote the development and improvement of such professionals, namely: open culture, leadership skills, and accelerated growth.

The remainder of the paper is organized as follows. In Section 2, we discuss the case study design and analyze the threats to validity. Results are presented in Section 3 and discussed in Section 4. Finally, we draw conclusions and provide directions for future work in Section 5.

\section{Case Study}

We followed the guidelines proposed by Runeson and Höst (2009) to design and report on this case study. The following subsections present the protocol details.

\subsection{Goal, Research Question and Subject Selection}

The main goal of this research is to investigate how the startup environment fosters the development and improvement of the leadership skills of technology professionals. In this context, we aimed to answer the following research question: 


\section{How do the startup environments foster \\ the development and improvement of the \\ leadership skills of technology professionals?}

Yin (2013) states that a case is a contemporary phenomenon in its real-life context. Considering such definition (YIN, 2013) and the guidelines of Runeson and Höst (2009), we classify this case study as explanatory (YIN, 2013).

The subjects selected for the study are professionals in the technology area and who already have responsibilities related to leadership, whether in people or in projects in a more comprehensive way. These subjects were chosen by the author's network of contacts and they work at Adiante S.A., a fintech based in São Paulo (SP). Each participant answered the characterization questions presented in Table 1.

Table 1. Subjects Characterization Form

\begin{tabular}{cl}
\hline Question \# & Question \\
\hline 1 & What is your level of education? \\
2 & How long have you been working in technology companies? \\
3 & How long have you working at Adiante S.A.? \\
4 & What is your position? \\
5 & How old are you? \\
\hline
\end{tabular}

In Table 2, we present an overview of the interviewed subjects.

Table 2. Subjects Overview

\begin{tabular}{ccllccc}
\hline Subject & Degree & $\begin{array}{l}\text { Time in } \\
\text { tech com- } \\
\text { panies } \\
\text { (years) }\end{array}$ & $\begin{array}{l}\text { Time } \\
\text { ante } \\
\text { anears) }\end{array}$ & $\begin{array}{l}\text { Adi- } \\
\text { (y. }\end{array}$ & Position & Age \\
& & 2 & 2 & Product Analyst & 25 \\
\hline 1 & Higher education & 2 & 1.3 & Programmer & 20 \\
2 & Higher education & 2.5 & 1.6 & Operations Director & 25 \\
3 & Higher education & 2 & 2 & Technology Director & 25 \\
4 & Master's & 5 & & & \\
\hline
\end{tabular}

\subsection{Data collection}

In the stage that refers to data collection, semi-structured interviews were conducted with the subjects selected for the study. The interview contained broad questions so that, as suggested by Strauss and Corbin (1998), we could extract all the possibilities of responses without being restricted to a pre-established direction by the researcher but without necessarily ignoring them completely.

In this study, we created a script for the interview, in order to cover questions at all levels of leadership in which the chosen subjects played a role. The questions can be seen in Table 3.

\subsection{Data Analysis and Synthesis}

According to Cresswell (1998), qualitative research is defined as an inquiry process of understanding based on distinct methodological traditions of inquiry that explore a social or 
Table 3. Interview Questions

\begin{tabular}{cl}
\hline Question \# & Question \\
\hline 1 & $\begin{array}{l}\text { How do you see the relationship between leadership and technology compa- } \\
\text { nies? }\end{array}$ \\
2 & $\begin{array}{l}\text { In your opinion, how important is leadership to work in this type of organiza- } \\
\text { tion? }\end{array}$ \\
3 & $\begin{array}{l}\text { What do you consider to be leadership skills? } \\
\text { Do you think that working at a startup, more specifically at a fintech, favored } \\
\text { you in developing these leadership skills? }\end{array}$ \\
5 & $\begin{array}{l}\text { In your opinion, how did the environment of this type of corporation foster } \\
\text { the development of your leadership skills, whether in people or in projects? }\end{array}$ \\
6 & $\begin{array}{l}\text { Which characteristic, within the skills you mentioned, do you consider the } \\
\text { main one to develop as a leader in this type of company? Why? }\end{array}$ \\
& What was the main difficulty you felt as a leader?
\end{tabular}

human problem. Qualitative interpretative research also emphasizes the researcher's interpretation based on the information provided by the research participants.

In this sense, we based the analysis of our acquired results on some procedures of Grounded Theory (STRAUSS; CORBIN, 1998) to analyze users' answers based on the concept of coding, such as: open coding makes possible identification of concepts that are separated into discrete parts for analysis; axial coding handles connections among codes and groups them according to their similarities; and selective coding refines the theory and finds the central category.

\subsection{Threats to Validity}

To describe the internal validity of empirical results, it is important to exclude or, at least, to explain confounding variables and other sources of potential bias (KITCHENHAM et al., 2002). One potential threat to internal validity (especially construct validity) in interviews refers to the fact that what a person is unable to record during data collection is usually as significant as what is collected. To mitigate such a threat, the interviews were recorded accurately and completely to ensure that the documented words and phrases are those of the person being observed and not a shorter form noted by the observer. The main threat to valid interpretation is to impose the meaning itself, instead of understanding the respondents' point of view and the meanings they attribute to their words, phrases and actions. To mitigate this threat, open-ended questions were used that allow the participant to elaborate responses and detail them as much as they wanted.

External validity is the extent to which conclusions can be generalized and capture the objectives of the study (KITCHENHAM et al., 2002). It is primarily concerned with the representativeness of the sample for the target population (CIOLKOWSKI et al., 2003). In this sense, the low number of interviews can be a threat, as there would not be enough information for analysis and subsequent answer to the research question. Therefore, some techniques of the Grounded Theory method (STRAUSS; CORBIN, 1998) were adopted to refine the data analysis and minimize the risk of not having enough information. 


\section{Results}

\subsection{Open Coding}

After conducting the scheduled interviews, we started the open coding process. In this stage, the recorded interviews were listened to in detail in order to extract the maximum codes from each question, performing the categorization of the data in order to start the foundation of the theory. Due to the nature of this study and for the next steps (axial coding and selective coding) to be better analyzed, the codes were, in this first step, divided according to the interview script (Section 2.2) and summarized for each interview. The extracted codes are shown in Table 4.

Table 4. Extracted Codes

\section{Question \# Interview \# $\operatorname{Code}(\mathbf{s})$}

\begin{tabular}{|c|c|c|}
\hline \multirow[t]{4}{*}{1} & 1 & Youthful environment, Need for skill, Freedom of Ideas \\
\hline & 2 & Need for skill, Organizational Control, Incentive \\
\hline & 3 & $\begin{array}{l}\text { Horizontal structure, Need for skill, Core business in tech- } \\
\text { nology, Exponential growth, Freedom of Ideas }\end{array}$ \\
\hline & 4 & $\begin{array}{l}\text { Friendly leadership, Youthful environment, Freedom of } \\
\text { Ideas, Targeting }\end{array}$ \\
\hline \multirow[t]{4}{*}{2} & 1 & Need for skill, Targeting, Freedom of Ideas \\
\hline & 2 & Need for skill, Targeting, Organizational Control, Incentive \\
\hline & 3 & Need for skill, Long-term horizon, Targeting \\
\hline & 4 & Targeting, Freedom of Ideas \\
\hline \multirow[t]{4}{*}{3} & 1 & Freedom of Ideas, Team skills \\
\hline & 2 & Organizational Control, Incentive, Team skills \\
\hline & 3 & Team skills, Organizational Control \\
\hline & 4 & Organizational Control, Problem solving \\
\hline \multirow[t]{4}{*}{4} & 1 & Favors development, Need for skill \\
\hline & 2 & Favors development, Need for skill, Freedom of Ideas \\
\hline & 3 & $\begin{array}{l}\text { Favors development, Need for skill, Gaps in the hierarchical } \\
\text { structure }\end{array}$ \\
\hline & 4 & Favors development, Freedom of Ideas \\
\hline \multirow[t]{4}{*}{5} & 1 & Freedom of Ideas, Team skills, Need for skill \\
\hline & 2 & Freedom of Ideas, Exponential growth \\
\hline & 3 & Gaps in the hierarchical structure, Youthful environment \\
\hline & 4 & Freedom of Ideas, Exponential growth \\
\hline \multirow[t]{4}{*}{6} & 1 & Freedom of Ideas, Youthful environment, Innovation \\
\hline & 2 & Organizational Control \\
\hline & 3 & Organizational Control \\
\hline & 4 & Organizational Control, Interpersonal relationship \\
\hline \multirow[t]{4}{*}{7} & 1 & Innovation, Targeting \\
\hline & 2 & Organizational Control, Problem solving \\
\hline & 3 & Targeting, Innovation \\
\hline & 4 & Organizational Control, Gaps in the hierarchical structure \\
\hline
\end{tabular}




\subsubsection{Interview 1}

As important points of this interview, the interviewee addressed a lot the need for leadership in this type of corporation. In addition, they highlighted the freedom to expose ideas as well as targeting fintechs: "[...] we always talk to people with an open mind[...]", "[...] there has to be someone to guide where things are going, what are the main points [...]". Also, no less important, the issue of taking leadership out of necessity was highlighted: "[...] I had some skills that I didn't have and I ended up having to develop, for example, to be more decisive $[\ldots] "$.

\subsubsection{Interview 2}

Interviewee 2, as they held a position related to software development, in which projects are well defined in terms of structuring and deadlines, showed great concern and focus on the issue of organization, present in almost all questions and identified with the code Organizational Control. A very striking example in the interview was the following excerpt: "[...] organization is key, programmers need to know what they're going to do [...]". Another point explored in this interview was the ability to teach, also identified by the interviewee, as in: "[...] the best leader is the one who teaches best [...]". Other interesting points raised in the interview that were reflected in new codes were the rapid growth of fintech and also the issue of all team members working on complex projects.

\subsubsection{Interview 3}

Since interviewee 3 holds a senior position in the corporation, it was possible to notice a much greater coverage in relation to de facto leadership and less specific points of sectors. Interesting points cited that reflected in the creation of new codes were: (i) the question of the horizontal structure of this type of corporation; and (ii) the existence of gaps in the hierarchical structure, providing an accelerated growth of employees who are willing to fill them: "[...] when we are talking about startups, you take a leadership position in 6 or 7 months [...] because there are gaps in the hierarchical structure that allow you to assume this role [...]".

A characteristic that was also approached in this interview was the youthful environment of this type of corporation, favoring and even facilitating this role of leader to be assumed by anyone, without much judgment of value in experience or age: "[...] you are dealing with people who are the same generation as you, [...], has a less conservative thinking and all this facilitates [...]".

\subsubsection{Interview 4}

The fourth interviewee also held a senior position, but more related to IT development and projects. There was a great concern with the issue of communication between the areas and the people of the team, taking this as a fundamental role for the leader: "[...] communication is the main point because there is a gap between demand and how it needs to reach developers [...] ". The exposure of ideas due to open culture was also addressed in this interview, this characteristic was listed as one of the most important for the development of leadership skills: "[...] they always open everything, we know everything and we can openly think about the best solution". 


\subsection{Axial Coding and Selective Coding}

After the open coding stage, in which the codes of each of the questions were extracted for all respondents, the reasoning part of the codes was made, i.e., the authors explain each identified code.

In this step, the axial and selective coding steps have also been carried out. We found that some codes created had the same foundation, and after analyzing these foundations, the categories were created. Table 5 shows the consolidated data (categories and codes) after the axial and selective coding steps.

Table 5. Coding Results

\begin{tabular}{|c|c|c|}
\hline Category & Code & Rationale \\
\hline \multirow[t]{5}{*}{ Open Culture } & Youthful environment & $\begin{array}{l}\text { Code identified in the data on the age group that makes up these or- } \\
\text { ganizations being low, average of } 25 \text { years old, and this facilitates the } \\
\text { interaction and the direction of the company, in addition to aligning val- } \\
\text { ues. }\end{array}$ \\
\hline & Freedom of Ideas & $\begin{array}{l}\text { Code identified in the interviewees' speech showing how the startup } \\
\text { environment collaborates in the development and improvement of lead- } \\
\text { ership skills, due to the culture of freedom and collaboration that they } \\
\text { have. }\end{array}$ \\
\hline & Horizontal structure & $\begin{array}{l}\text { Code that characterizes the type of hierarchical structure of these orga- } \\
\text { nizations. }\end{array}$ \\
\hline & Favors development & $\begin{array}{l}\text { Code identified from comments that the startup environment favored the } \\
\text { development of leadership skills. }\end{array}$ \\
\hline & Long-term horizon & $\begin{array}{l}\text { Code identified from the characteristic of the vision of results of these } \\
\text { corporations. }\end{array}$ \\
\hline \multirow[t]{5}{*}{ Leadership Skills } & Need for skill & $\begin{array}{l}\text { Code identified in the relationship presented by the interviewees be- } \\
\text { tween leadership and technology companies. For everyone, it is seen as } \\
\text { an interdependence in which there is a need for such a skill. }\end{array}$ \\
\hline & Targeting & $\begin{array}{l}\text { Code identified by the need for a guide that shows the way in these } \\
\text { corporations. }\end{array}$ \\
\hline & Organizational Control & $\begin{array}{l}\text { Code identified by being cited by some interviewees as a fundamental } \\
\text { leadership skill for a leader, since it covers the whole aspect of commu- } \\
\text { nication and interpersonal relationships. }\end{array}$ \\
\hline & Team skills & $\begin{array}{l}\text { Code identified as respondents consider leadership skills such as proac- } \\
\text { tivity, logical reasoning and technical knowledge important to all mem- } \\
\text { bers of the company. }\end{array}$ \\
\hline & Incentive & $\begin{array}{l}\text { Code identified when it was verified that, for the interviewees, all the } \\
\text { leaders with whom they have already worked were very solicitous and } \\
\text { showed a lot of interest in the professional development of their follow- } \\
\text { ers. }\end{array}$ \\
\hline \multirow[t]{5}{*}{ Accelerated growth } & Exponential growth & $\begin{array}{l}\text { Code identified for being a characteristic pointed out as important to } \\
\text { show why leadership is fundamental in startups. }\end{array}$ \\
\hline & Exposure to problems & $\begin{array}{l}\text { Code identified because it shows the fact that all employees are already } \\
\text { exposed to complex projects or to solve problems very quickly. }\end{array}$ \\
\hline & $\begin{array}{l}\text { Core business in tech- } \\
\text { nology }\end{array}$ & $\begin{array}{l}\text { Code identified because it shows that although a fintech is inserted, by } \\
\text { definition, in the financial market, the soul of the business and all its } \\
\text { intelligence is related to technology. }\end{array}$ \\
\hline & Innovation & $\begin{array}{l}\text { Code identified because it relates to the goal that startups, and particu- } \\
\text { larly fintechs, have and makes it very clear to everyone. }\end{array}$ \\
\hline & $\begin{array}{l}\text { Gaps in the hierarchical } \\
\text { structure }\end{array}$ & $\begin{array}{l}\text { Code identified from the report that the labor shortage itself due to the } \\
\text { accelerated pace of growth creates gaps that are filled based on the com- } \\
\text { pany's values and very quickly, generating great opportunities. }\end{array}$ \\
\hline
\end{tabular}

\section{Discussion}

Regarding the main goal of this research, namely Investigate how the startup environment fosters the development and improvement of the leadership skills of technology professionals, based on the results shown in Section 3, we have identified three main categories of 
factors that promote the development and improvement of such professionals: (i) open culture; (ii) leadership skills; and (iii) accelerated growth.

Open culture is a decisive factor in the development of leadership skills by technology professionals, as evidenced by the codes identified (Table 5). This characteristic makes the organizational environment conducive to the freedom of ideas and decision making by employees at all levels, so that everyone feels more free to exercise and consequently develop their leadership skills.

The second category identified and also of great importance is that of leadership skills proper. We can notice an interesting factor, highlighted in the code need for skill, which is the fact that the leadership characteristic, and consequently its already mentioned skills, is placed as fundamental in this type of corporation, corroborating with the collaboration of startup companies in the development skills due to the need of employees to have them.

Finally, we highlight the accelerated growth category, which is a typical characteristic of startups, and this growth gives rise to some unique opportunities. The very shortage of senior manpower and the lack of financial resources to bring it, makes employees themselves exposed much more quickly to challenging and highly responsible situations or projects. Thus, the leadership skills, which are already necessary in these organizations, are strongly developed.

Therefore, answering the research question posed in Section 2.1, the open culture and accelerated growth environment characteristic of a startup foster the development and improvement of the leadership skills of its employees. Such development and improvement occurs precisely as evidenced by the categories and codes already presented, that is, organizations of accelerated growth, with an open culture and a horizontal hierarchical structure, where leadership skills are often required, allow the development and improvement of such skills more naturally and as needed.

\section{Conclusions and Future Work}

In this paper we presented an investigation on how the startup environment fosters the development and improvement of the leadership skills of technology professionals. We conducted a case study with four subjects; data collection was carried out through semi-structured interviews with professionals from Adiante S.A. and the results obtained were analyzed qualitatively, with the support of some techniques of the Grounded Theory method.

In short, we can highlight that, as a result, we have identified three main categories of factors that promote the development and improvement of such professionals, namely: open culture, leadership skills, and accelerated growth. In other words, the open culture and accelerated growth environment characteristic of a startup foster the development and improvement of the leadership skills of its employees.

As future work, we intend to: (i) conduct more interviews at Adiante S.A. to refine the results obtained so far; (ii) conduct more interviews at other startups; and (iii) compare the results obtained in the various studies with those obtained in the present study.

\section{Acknowledgements}

The authors would like to thank the Brazilian funding agencies - São Paulo Research Foundation (FAPESP) under grant \#2018/15163-6; and CNPq under grant \#141010/2018-5. We also thank the practitioners from Adiante S.A. that participated in the interviews and the reviewers for their comments. 


\section{References}

BRUTON, G. D.; AHLSTROM, D.; LI, H.-L. Institutional theory and entrepreneurship: where are we now and where do we need to move in the future? Entrepreneurship theory and practice, SAGE Publications Sage CA: Los Angeles, CA, v. 34, n. 3, p. 421-440, 2010.

CIOLKOWSKI, M. et al. Practical experiences in the design and conduct of surveys in empirical software engineering. In: Empirical methods and studies in software engineering: Springer, 2003. p. 104-128.

COVEY, S. R. The 7 habits of highly effective people: Powerful lessons in personal change: Free Press, 2017.

CRESSWELL, J. W. Qualitative inquiry and research design: Choosing among five traditions: Thousand Oaks, CA: Sage, 1998.

DAFT, R. L. Management: Cengage Learning, 2021.

HISRICH, R.; BRUSH, C. The woman entrepreneur: Characteristics and prescriptions for success. Lexington, MA: Lexington Books, 1985.

HORNEY, N.; PASMORE, B.; O'SHEA, T. Leadership agility: A business imperative for a VUCA world. Human Resource Planning, v. 33, n. 4, p. 34, 2010.

ISMAIL, S. Exponential Organizations: Why new organizations are ten times better, faster, and cheaper than yours (and what to do about it): Diversion Books, 2014.

KITCHENHAM, B. A. et al. Preliminary guidelines for empirical research in software engineering. IEEE Transactions on software engineering, IEEE, v. 28, n. 8, p. 721-734, 2002.

LEE, I.; SHIN, Y. J. Fintech: Ecosystem, business models, investment decisions, and challenges. Business Horizons, Elsevier, v. 61, n. 1, p. 35-46, 2018.

LIDOW, D. Startup leadership: how savvy entrepreneurs turn their ideas into successful enterprises: John Wiley \& Sons, 2014.

RIES, E. The startup way: how modern companies use entrepreneurial management to transform culture and drive long-term growth: Currency, 2017.

RIES, E.; SAŁBUT, B. Metoda lean startup. Ediciones Deusto, 2012.

RUNESON, P.; HÖST, M. Guidelines for conducting and reporting case study research in software engineering. Empirical software engineering, Springer, v. 14, n. 2, p. 131, 2009.

SCHUMPETER, J. The instability of capitalism. The economic journal, JSTOR, v. 38, n. 151, p. 361-386, 1928.

STRAUSS, A.; CORBIN, J. Basics of qualitative research: Techniques and procedures for developing grounded theory: Thousand Oaks, CA: Sage, 1998.

THAI, M. T. T.; TURKINA, E. Macro-level determinants of formal entrepreneurship versus informal entrepreneurship. Journal of Business Venturing, Elsevier, v. 29, n. 4, p. 490-510, 2014.

YIN, R. Case Study Research: Design and Methods: SAGE Publications, 2013. ISBN 9781483322247.

ZAECH, S.; BALDEGGER, U. Leadership in start-ups. International Small Business Journal, SAGE Publications Sage UK: London, England, v. 35, n. 2, p. 157-177, 2017. 